\title{
Monitoring and population changes of Tuta absoluta (Meyrick, 1917) on tomato under greenhouse conditions in an arid expanse of south-eastern Algeria
}

\author{
Farid ALLACHE ${ }^{1}$, Fatma DEMNATI ${ }^{1,2,3}$
}

Received November 19, 2019; accepted April 30, 2020.

Delo je prispelo 19. novembra 2019, sprejeto 30. aprila 2020

\begin{abstract}
Monitoring and population changes of Tuta absoluta (Meyrick, 1917) on tomato under greenhouse conditions in an arid expanse of south-eastern Algeria

Abstract: The population changes of Tuta absoluta was surveyed during three growing seasons in greenhouse tomatoes in Biskra. Introduced in 2009 for the first time, it seems to be well established on tomato crops in Biskra; while their natural enemies remained lacking, due possibly to pesticides overuse. All pest stages were present on tomato plants during the three cropping seasons. Important numbers of males were captured during the first growing season and the least during the third growing season. The first adults' flight spread out between October and December. Adults' flight significantly rose at the end of the plant cycle due to increased temperatures in all cultivation seasons. This can provide information on the infestation levels for the following cultivation years. The numbers of immature were low during the three cultivation seasons. March, April and May seem more favorable to the different leaf miner instars development for the three cropping seasons. This was due probably to temperature rising.

Key words: population changes; Tuta absoluta; tomato crop; Biskra; Algeria
\end{abstract}

Spremljanje sprememb v populacijah paradižnikovega molja, Tuta absoluta (Meyrick, 1917), na paradižniku, gojenem v rastlinjakih v sušnih območjih jugo-vzhodne Alžirije

Izvleček: Spremembe v populaciji paradižnikovega molja (Tuta absoluta) so bile spremljane v treh rastnih sezonah na paradižniku v rastlinjakih v Biskri. Paradižnikov molj se je prvič pojavil leta 2009 in se je v nasadih paradižnika v Biskri dobro udomačil medtem, ko so njegovi naravni sovražniki še vedno odsotni, verjetno zaradi prevelike uporabe pesticidov. Vsi razvojni štadiji škodljivca so bili najdeni na paradižniku v vseh treh rastnih sezonah. Največje število samcev je bilo ujeto med prvo rastno sezono in najmanjše med tretjo rastno sezono. Prvi izlet odraslih žužel je bil med oktobrom in decembrom. Izlet odraslih se je značilno povečal proti koncu rastne sezone paradižnika zaradi dviga temperature $\mathrm{v}$ vseh rastnih sezonah, kar lahko kaže na stopnjo okužbe v naslednji rastni sezoni. Število nedoraslih osebkov je bilo majhno v vseh treh preučevanih sezonah. Marec, april in maj so bili najprimernejši za različne vmesne razvojne štadije minerjev v vseh treh rastnih sezonah, verjetno zaradi dviga temperature.

Ključne besede: spremembe populacij; Tuta absoluta; paradižnik; Biskra; Alžirija

1 University Mohamed Khider, Faculty of Exact Sciences, Nature and Life Sciences, Department of Agricultural Sciences, Algeria

2 University Mohamed Khider, Ecosystems Diversity and Agricultural Production Systems Dynamic Laboratory in Arid Zones (DEDSPAZA), Algeria

3 Corresponding author, e-mail: fat_demnati@yahoo.fr, f.demnati@univ-biskra.dz 


\section{INTRODUCTION}

Tomato crops, Lycopersicon esculentum Miller, are currently cultivated worldwide in greenhouses and in open fields (Lange \& Bronson, 1981). It is the most cultivated plant and largely consumed vegetable in Algeria after potatoes. The greenhouse tomato cultivation underwent a major expansion in the Sahara region and mainly in Ziban (Biskra) due to availability of water and good soil quality in certain localities. Biskra was ranked as the first producer of early vegetables nationally. Greenhouse crops are usually more exposed to fungal, viral and pest attacks due to elevated ambient moisture and temperature. The infestation can occur on plant aerial parts (stems, leaves, flowers, fruits) and/ or roots. The main pests of tomatoes are nematodes, insects or other arthropods (Lange \& Bronson, 1981). Tuta absoluta (Meyrick, 1917) is devastating pest of economic importance on tomato crops and other solanaceous crops (Medeiros et al., 2005; Bawin et al., 2017).The tomato borer leaf miner originates from South America. It is considered the most damaging pest of tomato crops in South America (Torres et al., 2001) since 1960s (Guedes \& Picanço, 2012); and is currently impacting crops in the Mediterranean countries of Europe and North Africa (Desneux et al., 2010; Caparros-Megido et al., 2012, 2013). Recently, it was found in Senegal (Pfeiffer et al., 2013). The larvae dig galleries in tomato leaves, fruit and stems (Picanço et al., 1998) and consequently open pathogen penetration pathways. Crops severely damaged can reach up to $100 \%$ of yield losses (Desneux et al., 2010). It harms several cultivated and wild plants (Vargas, 1970; Garcia \& Espul, 1982). It is new pest of tomatoes in Algeria, detected for the first time in 2008 in Mostaganem coastal region (Guenaoui, 2008) and in 2009 in Biskra (Allache \& Demnati, 2012; Allache et al., 2012). It became the most important pest of tomato crops in Algeria since 2008 (Gacemi \& Guenaoui, 2012) due to its severe damage observed in greenhouses and open fields (Badaoui \& Berkani, 2010). Chemical control was the main method used in South American countries to manage this pest. Unfortunately, these chemicals, have caused insects resistance, leaving residue on food products and in the environment; threatening human safety and have eradicated beneficial insects (Siqueira et al., 2000, 2001; Lietti et al., 2005). In South America, the pest is faced with several insects parasitoids and predators including, the egg parasitoid Trichogramma spp. (Medeiros et al., 2011); and many others antagonist of different stages (Sanchez \& Redolfi de Huiza, 1985; Desneux et al., 2010). Some have been tested and used in biological control against $T$. absoluta with promising results. The mirid bugs Nesidiocoris tenuis (Reuter, 1895) and Macrolophus pygmaeus (Rambur, 1839) were the most tested bugs.
Larvae and adults are known to be consumers of eggs and larvae of T. absoluta (Urbaneja et al., 2009). The knowledge of biological processes and development of this pest in the arid agricultural systems of Biskra is important to establish an efficient management program. The objective of this research was to monitor population dynamics of Tuta absoluta in tomato crop during three growing seasons in Biskra.

\section{MATERIALS AND METHODS}

\subsection{STUDY SITE}

The study was carried out in the south east of Algeria in the province of Biskra $\left(34^{\circ} 51^{\prime} 01^{\prime \prime} \mathrm{N}, 5^{\circ} 43^{\prime} 40^{\prime \prime} \mathrm{E}\right)$. Currently, Tuta absoluta was found exclusively on tomato crops which are cultivated essentially under greenhouse conditions in Biskra. The infestation of tomato plants in the studied greenhouses occurred naturally. Tomato production has significant economic value at local and national level. The losses produced by this pest can be considerable. The crops were set up in late September and early October. During the study, tomato diseases and pests were recorded, including mainly botrytis, alternaria, mites, whiteflies, aphids, moth, agromyzid leaf miner and thrips. These pests were subjected to chemical treatments used by the farmers. Usually, tomato crop dries towards May due to high temperatures characterizing the region.

\subsection{INSECT ADULTS MONITORING}

Population development of Tuta absoluta was surveyed over three seasons. Adult monitoring started from the transplanting of plants until its desiccation. The survey was conducted in tomato greenhouses with a surface area of $400 \mathrm{~m}^{2}$ (50 m in length and $8 \mathrm{~m}$ wide) containing about 800 plants. The distance between plants line was $1 \mathrm{~m}$ and between plants was $40 \mathrm{~cm}$. Two traps Delta type (Russell IPM) equipped with pheromone capsules were used, at $1 \mathrm{~m} 20 \mathrm{~cm}$ from the ground surface, for capturing adults; they were placed in each greenhouse entrance separated by $30 \mathrm{~m}$ from each other. The pheromone capsules were renewed each month. The number of adults was recorded every week. The objective of traps was, first to detect the beginning of adult flight and secondly to study population changes.

\subsection{SAMPLING METHOD OF IMMATURE STAGES}

To investigate the immature stages (eggs, larvae 
and pupae), sampling of leaves was important (Allache \& Demnati, 2012; Allache et al., 2012). Immature stages can be encountered on all plant parts; but in this work, sampling concerned only leaves. Twenty leaves were collected randomly every week, and they were put individually in paper bags. Sampling of leaves started three weeks after plant transplantation depending on plant vigor. The leaves were brought back to laboratory and observed under a binocular magnifying glass. Eggs, larvae and pupae were then counted on each tomato leaf.

\subsection{STATISTICAL ANALYSIS}

Data obtained were normalized using a square root transformation $(x+0.5)$ before analysis. An ANOVA test was performed to differentiate between means and a LSD test for means comparison using a $5 \%$ level of significance was applied.

\section{RESULTS}

\subsection{TOTAL INDIVIDUALS COLLECTED}

The total and average numbers of the different developmental stages of T. absoluta on tomato were monitored for three cropping seasons. Over the three cropping seasons, the rates of adults caught during the 2009/2010 season was high $(43.96 \%)$ compared to the two subsequent seasons. The captures were low in 2010/2011 and $2011 / 2012$, amounting to respectively 28 and $27 \%$. The lowest number of males was caught in 2011/2012 growing season. The high number of catches was recorded particularly towards the end of the crop cycle. ANOVA analysis showed that adults caught were not significantly different between the three growing seasons $(p>0.05)$ (Table 1).

In October, a large number of adults were trapped during the 2011/2012 growing season. The least adults' captured was recorded in November. During the 2011/2012 growing season, March appears to be the most prolific concerning the number of adult caught. The number of caught individuals was most important in April for the 2009/2010 growing season. May was the most prolific month for the cropping season 2010/2011, the number of adults captured was important compared to the two other cropping years (Table 2).

Concerning total eggs laid on leaves, it was found that during the first crop season (2009/2010), a large numbers were recorded compared to the second and third cultivation growing seasons (Table 1). ANOVA analysis showed a significant difference between these three crop seasons $(F=8.96, p=0.000)$. LSD test performed between the second and the third year revealed no difference $(p=0.116)$.

The number of eggs deposited was more pronounced from March. Majority of eggs were deposited on leaves during the 2009/2010 cropping season (March-April); and in May for the 2010/2011 growing season (Table 2).

Larval activity on leaves varied during and between the crop campaigns (Table 1). The most important activity was registered in the 2009/2010 growing season and the lowest during the 2011/2011 season. ANOVA analysis showed significant differences between larval numbers during these growing seasons $(F=17.90, p=0.000)$. From December to April, during the growing season 2009/2010, the number of larvae recorded was most important compared to the two next crop years. However, a significant number was registered in May during the 2010/2011 cultural season (Table 2).

The pupae number recorded was very low and variable between all crop seasons. During the third season, only two pupae were counted on tomato leaves. The most important number of pupae collected was during the 2009/2010 crop season. ANOVA tests demonstrated significant differences between growing seasons $(F=24.18$; $p=0.000$ ); no difference was noted between the second and the third year $(p=0.131)$. An absence of pupae was observed during the growing season 2011/2012. Even so, the most important pupae numbers were noted during the 2009/2010 growing season. March, April and May appear most favorable to pupation of T. absoluta (Table 2).

We noted a lack of presence and activity of most

Table 1: Comparison of means of the different stages of Tuta absoluta between crop seasons

\begin{tabular}{|c|c|c|c|c|}
\hline \multirow[b]{2}{*}{ Crop season } & \multicolumn{4}{|c|}{ Insect stage $($ Mean $\pm \mathrm{SD})$} \\
\hline & Adults & Eggs & Larvae & Pupae \\
\hline $2009 / 2010$ & $71.57 \pm 102.21^{\mathrm{a}}(2004)$ & $20.07 \pm 18.83^{\mathrm{a}}(562)$ & $33.89 \pm 19.50^{a}(949)$ & $5.82 \pm 4.62^{\mathrm{a}}(163)$ \\
\hline $2010 / 2011$ & $46.25 \pm 131.89^{\mathrm{a}}(1295)$ & $10.00 \pm 14.33^{\mathrm{b}}(280)$ & $13.11 \pm 28.96^{\mathrm{b}}(367)$ & $1.39 \pm 3.18^{\mathrm{b}}(39)$ \\
\hline $2011 / 2012$ & $45.00 \pm 47.18^{\mathrm{a}}(1260)$ & $3.86 \pm 8.27^{\mathrm{b}}(108)$ & $1.93 \pm 4.01^{c}(54)$ & $0.07 \pm 0.26^{\mathrm{b}}(2)$ \\
\hline
\end{tabular}

LSD test was used to differentiate between means. The values in the columns with the same lowercase letter are not statistically different (confidence level $p<0.05)$. Values in parentheses represent the total of detected individuals at each different stage of Tuta absoluta. 


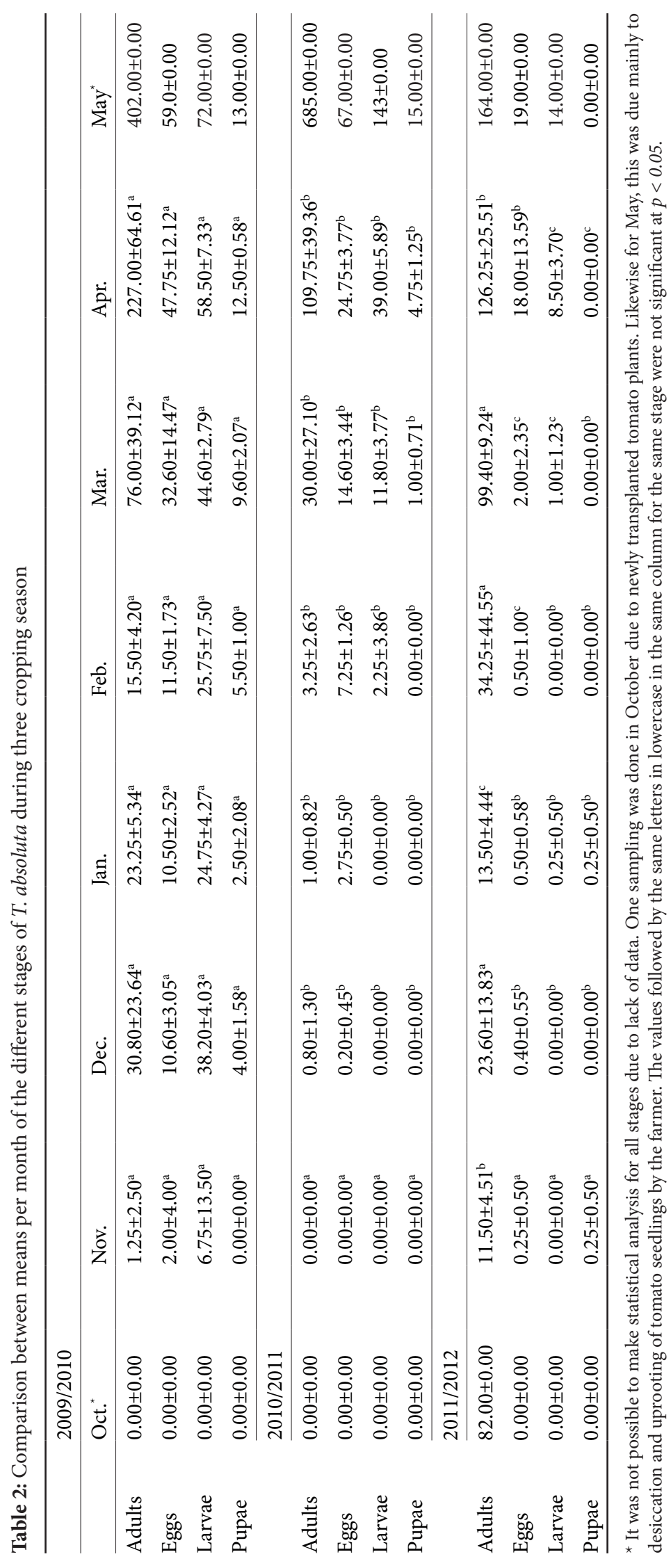




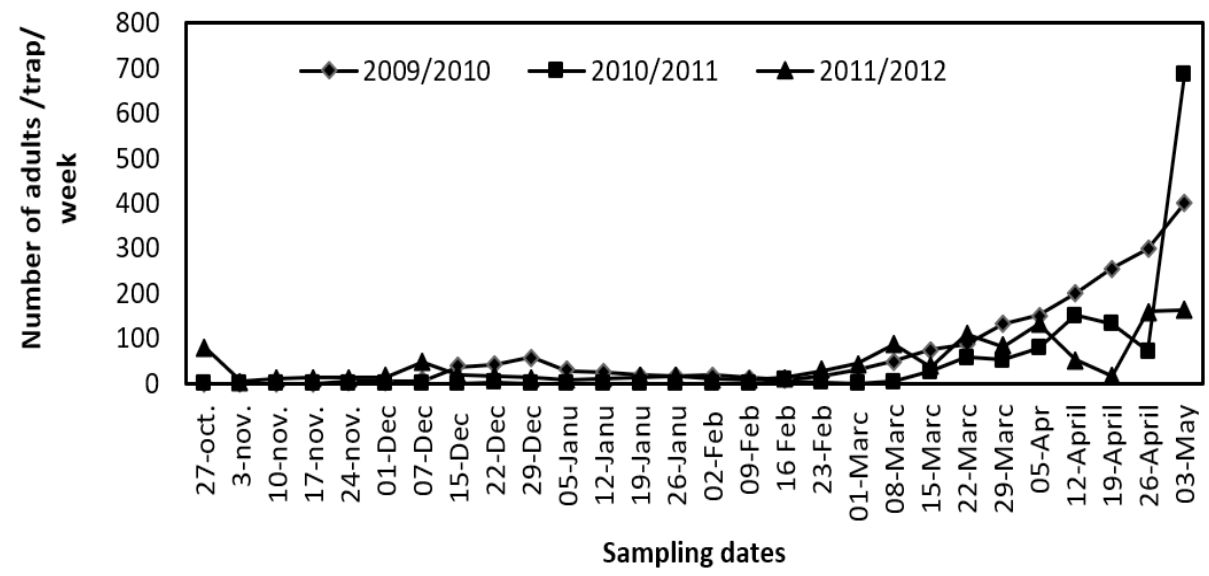

Figure 1: Flight activity and population changes in pheromone traps of Tuta absoluta males in Biskra greenhouses during three cropping campaigns $(2009 / 2010 ; 2010 / 2011 ; 2011 / 2012)$

common natural enemies of the leaf miner tomato borer during the three cropping seasons.

\subsection{FLIGHT ACTIVITY AND POPULATION CHANGE OF ADULTS}

The first flight of adults of T. absoluta was recorded in pheromone traps on November $24^{\text {th }}, 2009$ for the first growing season, December $15^{\text {th }}, 2010$ for the second and earlier for the third year (October 27 $7^{\text {th }}, 2011$ ) (Figure 1).

Adults occurred during all tomato phenological cycles. At the beginning of the tomato cultivation season, the numbers of male caught in pheromone traps was low. Thereafter, this number became very important towards the end of the tomato cycle. The observations revealed intense adult activity with increasing temperatures from the end of February until crop harvest for the three growing seasons. Development changes of T. absoluta adults for the different growing seasons was highly significant (2009-2010: $F=37.93$, $p=0.000 / 2010-2011: F=182.86, p=0.000 / 2011-2012$ : $F=5.65, p=0.000)$. The number of individuals caught in traps ranged from 5 to 402 adults in the first growing season (2009/2010); four peaks were registered. During the 2010/2011 crop season, between 1 and 685 adults were captured, with three peaks observed. In the third cropping season (2011/2012), there were between 5 and 164 adults, with six peaks observed. The population of tomato leaf miner borers increased with time in the three cropping seasons; most adults number were trapped in spring.

\section{DISCUSSION}

The survey was conducted throughout all pheno- logical plant cycles. Tomato crops seem to be the only host plant used by Tuta absoluta in Biskra. This was also reported by Allache et al. (2012), while Vargas (1970), Garcia \& Espul (1982) and Guenaoui et al. (2011), reported their development on several plants belonging to cultivated and wild solanacous species. Tuta absoluta seems to be well established in this location given the continual presence throughout the plant cycle and during the three cropping seasons. Currently it is among the major pests that cause important threats on tomato crop in Algeria. There were very few captured males early in the growing season due to low temperatures. This number gradually increased during the end of the cropping season. Similar observations were stated by Cocco et al. (2013, 2015), Cherif \& Lebdi-Grissa (2014) and Harbi et al. (2015). Balzan \& Moonen (2012) underlining exponential growth of $T$. absoluta captured during warmer periods and high numbers at crop harvest. These may be due to increased temperatures (Lacordaire \& Feuvrier, 2010; Allache et al., 2015). Whereas El-Aassar et al. (2015) highlighted a decrease in population of T. absoluta caught.

In October, during the third cultivation season (2011/2012), an important number of adults were trapped. These high captures can be due to population built-up during the previous cultivation season as suggested by Cocco et al. (2013).

The adult flight activity takes place during the same period in autumn; which means when the summer-autumn temperatures become favorable (decline in high temperatures in late September), the adults' flight is activated. Martins et al. (2016) reported an upper and lower limit of development temperatures estimated between $14^{\circ} \mathrm{C}$ and $35^{\circ} \mathrm{C}$. Unlike the present study, Mamay \& Yanik (2012) reported an adult flight activity much later, in early May in Şanliurfa 
(Turkey); and in January in Takelsa, Tunisia (Cherif et al., 2013).

In absence of cultivated tomatoes during intercropping periods, alternative host species can serve as infestation reservoirs for the tomato leaf miner borers (Cocco et al., 2015). Given the extreme temperatures in Biskra during the summer, all plants potentially favorable for its development will dry out at that time. A study of aestivation form of T. absoluta is needed in this location to build a pest control plan before adults' flight activity.

Knowing the first adults' flight and major flight activity periods are important for farmers to take appropriate pest control decisions. According to Cherif et al. (2013), information about the population structure combined with adults' flight activity are essential to control this pest and to determine the best intervention time according to larvae sensitivity and extent of damage.

All T. absoluta instars were present on tomato leaves in the greenhouses during all cropping seasons. This is confirmed by the results obtained by Lebdi-Grissa et al. (2010) and Cocco et al. (2015). The tomato leaves were more attractive to the females' egg laying (Galdino et al., 2015; Salama et al., 2015). In this study, the amounts of eggs deposited on leaves were low; even so, 2009/2010 cropping season was the year which more eggs were laid.

Important numbers of eggs were noticed in Marsh, April and May. These numbers were low in 2010/2011 and 2011/2012 cropping years. This was most likely due to low temperatures early in the season during the egg hatching. Likewise, Cherif \& Lebdi-Grissa (2014) registered low egg numbers during the autumn-winter period; this number increased in spring. After the same authors, the leaf miner T. absoluta development was related to temperature. Remating of Tuta absoluta increased number of eggs laid, fertility and female longevity (Lee et al., 2014). Sampling methodology can also explain low egg numbers. Lebdi-Grissa et al. (2010) indicated that eggs were laid on young leaves; however, in the present study, sample of leaves were taken on the middle part of the plants.

Tuta absoluta larvae were present throughout all stages of the phenological plant cycle during the 2009/2010 cropping season; these numbers were more important compared to the two subsequent seasons. March, April and May appeared to be very favorable for larval development, perhaps because the 2009/2010 crop season was warmer than the following years. It may also be due to larvae movement; it should be noted that leaves were sampled essentially in the middle canopy. Galdino et al. (2015) reported that older larvae can move around the plant, to young leaves, with more nutrition, increasing their performance. The same authors reported that larvae were able to identify sites on plants where their performances are high.

Larvae of leaf miners reaching pupae stage in leaf tissue appeared very low, principally for the second and the third cropping seasons. This may be due to larval pupation, which was performed generally in the ground; however, some old larvae complete their developmental stage in leaf galleries (Lebdi-Grissa et al., 2010). The abiotic factor like temperature (Lebdi-Grissa et al., 2010); and biotic factors like, larval natural mortality, pupae viability and nutritional quality of the plants could have an effect on leaf miner development (Torres et al., 2001). Furthermore, to the sampling procedure which don't take in consideration pupae fallen on the ground or to larval chemical control (Allache et al., 2012). According to Coelho and França (1987), very little larval pupation takes place on leaves, stems and fruit; this could be the cause for the low numbers found in this study.

Our study showed that at the end of the third year, the pests were well installed and continually present on the tomato crop, while predators were not found. On the contrary, Cocco et al. (2015) observed parasitoid activity on potato and tomato crops during a 2-years study. In Jordan, Al-Jboory et al. (2012) noted three hemipteran insects and one parasitic wasp on T. absoluta. Unlike the present study, Mahdi et al. (2011) recorded two predatory mirid bugs in Mitidja (Algiers) (Nesidiocoris tenuis (Reuter, 1895) and Macrolophus caliginosus (Wagner 1951)) and a parasitic eulophid wasp Diglyphus spp. Several natural enemies could develop on T. absoluta depending on its dispersion area of origin. Some of these species are used successfully in biological control with appreciable levels of parasitism (Desneux et al., 2010).

The main causes for the lack of tomato leaf miner borer antagonists in the study area can be explained by their sensitivity and the overuse of pesticides by the farmers in pest control programs.

\section{CONCLUSION}

The rising temperatures influenced the development of Tuta absoluta. This pest seems well established in tomato crops in Biskra. Thus their natural enemies were not found during this study. Increased knowledge about adult flight dates and population changes is important to develop an efficient control strategy.

Changing farmer behavior and control method (which was mainly chemical) and developing other strategies based on safer environmental techniques are fundamental for providing antagonists possibility, time and space to develop.

In Italy, Balzan \& Moonen (2012) suggested changes 
of the current strategies used. They stated that frequent use of pesticides not only disrupts the biological control but also makes the agroecosystems more susceptible to pest invasions; which leads to a dependence on external inputs of antagonists. Harbi et al. (2012) considered that insect-proof screens combined with sex pheromone mass trapping can be very efficient to decrease T. absoluta populations. However Cherif et al. (2013) discussed the unsuitability for egg laying of certain plant varieties, which can provide effective prophylactic techniques for reducing $T$. absoluta infestation.

\section{ACKNOWLEDGEMENTS}

The authors would like to thank Dr. L. Ernoul for proofreading the text, the farmers of Biskra for their help and, Mr. A. Hadjeb and Aoun S. who providing us Tuta absoluta pheromone capsules, traps and tomato seeds. This work is supported by the PRFU project (D04N01UN070120190001).

\section{REFERENCES}

Al-Jboory, I. J., Katbeh- Bader, A., \& Al-Zaidi, S. (2012). First observation and identification of some natural enemies collected from heavily infested tomato by Tuta absoluta (Meyrick) (Lepidoptera: Gelechiidae) in Jordan. Middle-East Journal of Scientific Research, 11, 435-438.

Allache, F., Bouta, Y., \& Demnati, F. (2015). Population development of the tomato moth Tuta absoluta (Lepidoptera: Gelechiidae) in greenhouse tomato in Biskra, Algeria. Journal of Crop Protection, 4, 509-517.

Allache, F., \& Demnati, F. (2012). Population changes of Tuta absoluta (Mey.) (Lepidoptera, Gelichiidae): a new introduced tomato crop pest at Biskra in Algeria. Jordan Journal of Agricultural Science, 8, 391-400.

Allache, F., Houhou, M. A., Osmane, I., Naili, L., \& Demnati, F. (2012). Suivi de lévolution de la population de Tuta $a b$ soluta Meyrick (Gelichiidae), un nouveau ravageur de la tomate sous serre à Biskra (sud-est d'Algérie). Entomologie Faunistique - Faunistic Entomology, 65, 149-155.

Badaoui, M. I., \& Berkani, A. (2010). Morphologie et comparaison des appareils génitaux de deux espèces invasives Tuta absoluta Meyrick 1917 et Phthorimaea operculella Zeller 1873 (Lepidoptera: Gelechiidae). Entomologie faunistique Faunistic Entomology, 63, 191-194.

Balzan, M. V., \& Moonen, A. C. (2012). Management strategies for the control of Tuta absoluta (Lepidoptera: Gelechiidae) damage in open-field cultivations of processing tomato in Tuscany (Italy). Bulletin OEPP/EPPO Bulletin, 42, 217-225. https://doi.org/10.1111/epp.2558

Bawin,T., Collard, F., De Backer, L., Yarou, B. B., Compère, P., Francis,F., \& Verheggen, F. J. (2017). Structure and distribution of the sensilla on the antennae of Tuta absoluta
(Lepidoptera: Gelechiidae). Micron, 96, 16-28. https://doi. org/10.1016/j.micron.2017.01.008

Caparros-Megido, R., Haubruge, E., \& Verheggen, F. J. (2012). First evidence of deuterotokous parthenogenesis in the tomato leafminer, Tuta absoluta (Meyrick) (Lep., Gelechiidae). Journal of Pest Science, 85, 409-412. https://doi. org/10.1007/s10340-012-0458-6

Caparros-Megido, R., Haubruge, E., \& Verheggen, F. J. (2013). Pheromone-based management strategies to control the tomato leafminer, Tuta absoluta (Lepidoptera: Gelechiidae). Biotechnologie, Agronomie, Société, Environnement, 17, 475-482.

Cherif, A., \& Lebdi-Grissa, K. (2014). Control of the tomato leafminer Tuta absoluta (Lepidoptera; Gelechiidae) using the mass trapping tool in tomato open field plot and greenhouses in Tunisia. Agricultural Science Research Journal, 4(10), 161-173.

Cherif, A., Mansour, R., \& Grissa-Lebdi, K. (2013). Biological aspects of tomato leafminer Tuta absoluta (Lepidoptera: Gelechiidae) in conditions of northeastern Tunisia: possible implications for pest management. Environmental and Experimental Biology, 11, 179-184.

Cocco, A., Deliperi, S., \& Delrio, G. (2013). Control of Tuta absoluta (Meyrick) (Lepidoptera: Gelechiidae) in greenhouse tomato crops using the mating disruption technique. Journal of Applied Entomology, 137, 16-28. https://doi. org/10.1111/j.1439-0418.2012.01735.x

Cocco, A., Deliperi, S., Lentini, A., Mannu, R., \& Delrio, G. (2015). Seasonal phenology of Tuta absoluta (Lepidoptera: Gelechiidae) in protected and open-field crops under Mediterranean climatic conditions. Phytoparasitica, 43, 713-724. https://doi.org/10.1007/s12600-015-0486-x

Coelho, M. C. F., \& França, F. H. (1987). Biologia e quetotaxia da larva e descriçao da pupa e adulto da traça do tomateiro. Pesquisa Agropecuaria Brasileira, 22, 129-135.

Desneux, N., Wajnberg, E., Wyckhuys, K. A. G., Burgio, G., Arpaia, S., Narvaez-Vasquez C. A., Gonzalez-Cabrera J., Ruescas D. C., Tabone, E., Frandon, J., Pizzol, J., Poncet C., Cabello, T., \& Urbaneja, A., (2010). Biological invasion of European tomato crops by Tuta absoluta: ecology, geographic expansion and prospects for biological control. Journal of Pest Science, 83, 197-215. https://doi. org/10.1007/s10340-010-0321-6

El-Aassar, M. R., Soliman, M. H. A., \& Abd Elaal, A. A. (2015). Efficiency of sex pheromone traps and some bio and chemical insecticides against tomato borer larvae, Tuta absoluta (Meyrick) and estimate the damages of leaves and fruit tomato plant. Annals of Agricultural Science, 60, 153-156. https://doi.org/10.1016/j.aoas.2015.05.003

Gacemi, A., \& Guenaoui, Y. (2012). Efficacy of emamectin benzoate on Tuta absoluta Meyrick (Lepidoptera: Gelechiidae) infesting a protected tomato crop in Algeria. Academic Journal of Entomology, 5, 37-40.

Galdino, T. V. Ds., Picanço, M. C., Ferreira, D. O., Silva, G. A. R., Souza T. C. D., \& Silva G. Ad. (2015). Is the performance of a specialist herbivore affected by female choices and the adaptability of the offspring? PLoS ONE, 10, e0143389. https://doi.org/10.1371/journal.pone.0143389

Garcia, M. F., \& Espul, J.C., (1982). Bioecology of the tomato 
moth (Scrobipalpula absoluta) in Mendoza, Argentine Republic. Revista de Investigaciones Agropecuarias, 17, 135146.

Guedes, R. N. C., \& Picanço, M. C. (2012). The tomato borer Tuta absoluta in South America: pest status, management and insecticide resistance. EPPO Bulletin, 42, 211-216. https://doi.org/10.1111/epp.2557

Guenaoui, Y. (2008). Nouveau ravageur de la tomate en Algérie: première observation de Tuta absoluta, mineuse de la tomate invasive, dans la région de Mostaganem, au printemps 2008. Phytoma-La Défense des Végétaux, 617, 18-19.

Guenaoui, Y., Bensaad, R., \& Ouezzani, K. (2011). Importance of native polyphagous predators able to prey on Tuta absoluta Meyrick (Lepidoptera: Gelechiidae) on tomato crop. In Proceedings of the EPPO/IOBC/FAO/NEPPO Joint International Symposium on management of Tuta absoluta, November 16-18, 2011, Agadir, Morocco.

Harbi, A., Abbes, K., \& Chermiti, B. (2012). Evaluation of two methods for the protection of tomato crops against the tomato leafminer Tuta absoluta (Meyrick) under greenhouses in Tunisia. EPPO Bulletin, 42, 317-321. https://doi. org/10.1111/epp. 2576

Harbi, A., Abbes, K., Dridi-Almohandes, B., \& Chermiti, B. (2015). Efficacy of insect-proof nets used in Tunisian tomato greenhouses against Tuta absoluta (Meyrick) (Lepidoptera: Gelechiidae) and potential impact on plant growth and fruit quality. Journal of Entomological and Acarological Research, 47, 109-116. https://doi.org/10.4081/jear.2015.5256

Lacordaire, A. I., \& Feuvrier, E. (2010). Tomate, traquer Tuta absoluta. Phytoma La Défense des Végétaux, 632, 40-44.

Lange, W. H., \& Bronson, L. (1981). Insect pests of tomatoes. Annual Revue of Entomology, 26, 345-371. https://doi. org/10.1146/annurev.en.26.010181.002021

Lebdi-Grissa, K., Skander, M., Mhafdhi, M., \& Belhadj, R. (2010). Lutte intégrée contre la mineuse de la tomate, Tuta absoluta Meyrick (Lepidoptera: Gelechiidae) en Tunisie. Entomologie faunistique - Faunistic Entomology, 63, 125132.

Lee, M. S., Albajes, R., \& Eizaguirre, M. (2014). Mating behaviour of female Tuta absoluta (Lepidoptera: Gelechiidae): polyandry increases reproductive output. Journal of Pest Science, 87: 429-439. https://doi.org/10.1007/s10340-0140576-4

Lietti, M. M. M., Botto, E., \& Alzogaray, R. A. (2005). Insecticide resistance in Argentine populations of Tuta absoluta (Meyrick) (Lepidoptera: Gelechiidae). Neotroptropical Entomology, 34, 113-119. https://doi.org/10.1590/S1519566X2005000100016

Mahdi, K., Doumandji-Mitiche, B., Ababsia, A., \& Doumandji, S. (2011). Les ennemis naturels de la mineuse de la tomate Tuta absoluta (Meyrick, 1917) en Algérie : perspectives de lutte biologique. AFPP- Quatrième Conférence Internationale sur les Méthodes Alternatives en Protection des Cultures, 8, 9 et 10 mars, Lille, France.

Mamay, M., \& Yanik, E. (2012). Determination of adult population development of Tomato leafminer [Tuta absoluta
(Meyrick) (Lepidoptera: Gelechiidae)] in tomato growing areas in Şanlıurfa. Turkish Bulletin of Entomology, 2, 189198.

Martins, J. C., Picanço, M. C., Bacci, L., Guedes, R. N. C., Santana, Jr. P. A., Ferreira, D. O., \& Chediak, M. (2016). Life table determination of thermal requirements of the tomato borer Tuta absoluta. Journal of Pest Science, 89, 897-908. https://doi.org/10.1007/s10340-016-0729-8

Medeiros, M. A., Sujii E. R., \& Morais, H. C. (2011). Fatores de mortalidade na fase de ovo de Tuta absoluta em sistemas de produção orgânica e convencional de tomate. Bragantia, 70, 72-80. https://doi.org/10.1590/S0006-87052011000100012

Medeiros, M. A., Villas Boas, G. L., Carrijo, O. A., Makishima, N., \& Vilela, N.J. (2005). Manejo integrado da traça-dotomateiro em ambiente protegido. Embrapa hortaliças, Circular Técnica, 36, 10.

Pfeiffer, D. G., Muniappan, R., Sall, D., Diatta, P., Diongue, A., \& Dieng, E. O. (2013). First Record of Tuta absoluta (Lepidoptera: Gelechiidae) in Senegal. Florida Entomology, 96, 661-662. https://doi.org/10.1653/024.096.0241

Picanço, M. C., Leite, G. L. D., Guedes, R. N. C., \& Silva, E. A. (1998). Yield loss in trellised tomato affected by insecticidal spray and plant spacing. Crop Protection, 17, 447-452. https://doi.org/10.1016/S0261-2194(98)00040-4

Salama, H. S. A., Ismail, I. A., Fouda, M., Ebadah, I., \& Shehata, I. (2015). Some ecological and behavioral aspects of the tomato leaf miner Tuta absoluta (Meyrick) (Lepidoptera: Gelechiidae). Ecologia Balkanica, 7, 35-44.

Sanchez, G., \& Redolfi De Huiza, I. (1985). Parasitoides de Liriomyza huidobrensis y Scrobipalpula absoluta en papa cultivada en Lima, 1984. Revista Peruana de Entomologia, 28, $81-83$.

Siqueira, H. A. A., Guedes, R. N. C., \& Picanço, M. C. (2000). Insecticide resistance in populations of Tuta absoluta (Lepidoptera: Gelechiidae). Agriculture and Forest Entomology, 2, 147-153. https://doi.org/10.1046/j.1461-9563.2000.00062.x

Siqueira, H. A. A, Guedes, R. N. C., \& Picanço, M. C. (2001). Abamectin resistance synergism in Brazilian populations of Tuta absoluta (Meyrick) (Lepidoptera: Gelechiidae). International Journal of Pest Management, 47(4), 247-251. https://doi.org/10.1080/09670870110044634

Torres, J. B, Faria, C. A, Evangelista, W. S, \& Pratissoli, D. (2001). Within-plant distribution of the leaf miner Tuta absoluta (Meyrick) immatures in processing tomatoes, with notes on plant phenology. International Journal of Pest Management, 47(3), 173-178. https://doi. org/10.1080/02670870010011091

Urbaneja, A., Monton, H., \& Molla, O. (2009). Suitability of the tomato borer Tuta absoluta as prey for Macrolophus pygmaeus and Nesidiocoris tenuis. Journal of Applied Entomology, 133, 292-296. https://doi.org/10.1111/j.14390418.2008.01319.x

Vargas, H. C. (1970). Observaciones sobre la biología y enemigos naturales de la polilla del tomate, Gnorimoschema absoluta (Meyrick) (Lepidoptera: Gelechiidae). Idesia, 1, $75-110$. 